\title{
Economic empowerment through Kaaps
}

\author{
Christo van der Rheede \\ Chairperson, AgriSeta
}

Correspondence to: crheede@gmail.com

\begin{abstract}
As a regional variety, Kaaps can be seen as a driver of social, cultural, educational and economic interaction in specific contexts. However, the economic value of Kaaps and its role in economic empowerment in these contexts have not yet been properly researched. This chapter aims to inspire scholars to do in-depth research on the role that Kaaps already plays in the regional economy, as well as the role it can play as principal driver of many other commercial and artistic projects.
\end{abstract}

\section{INTRODUCTION}

Economic empowerment through Kaaps is a challenging topic. The economic value of the regional dialect known as Cape Vernacular Afrikaans (Ponelis 2009), which is also called Kaaps, has not as yet received sufficient attention, nor has the question of the variety's potential role in the economic empowerment of its speakers.

However, a different story is told by the growth in circulation of tabloid newspapers like Son, Voice, magazines like Kuier and the accompanying financial success and popularity of TV entertainment like Jou Show on Kyknet by leading entertainer Emo Adams, the music of local artists like Brasse vannie Kaap, Jack Parow, D Low, the works of Adam Small and many more, the performances by comedians like
Mark Lottering and the stars of Joe Barber, as well as numerous theatre productions like AfriKaaps, Kap 'an and musicals like District Six and Ghoema! In these enterprises, Kaaps is used as the key driver for commercial and artistic reasons. The profit motive is, of course, important for the print and electronic media, the television industry, music and theatre productions. Hence, such publications and productions are also characterised by a strong entrepreneurial approach, creativity, a comprehensive marketing plan and a clear focus on a particular target market.

The realisation of the economic potential of Kaaps is therefore not the product of our imagination. Positioning Kaaps as a language of economic empowerment and wealth creation for the mass of its speakers demands 
a focused approach aimed at specific outcomes. It involves the following:

- To change the perception of Kaaps as an inferior language with no economic value;

- To place the economic positioning of Kaaps on a developmental theoretical foundation;

- To do an economic analysis of the Kaaps speech communities;

- To identify domains within which the economic value of Kaaps can be exploited with the aim of wider economic empowerment;

- To highlight the factors which influence demand and supply, as well as the success stories of artists working in Kaaps;

- To emphasize the importance of legal aspects like copyright;

- To conceptualize a foundation for a strategic and operational plan which promotes Kaaps as a language of economic empowerment.

Thischapter providesaconsideration of the economic exploitation of Kaaps as a variety spoken by a significant number of brown people in the Cape Peninsula and its surrounding areas, and specifically in many domains - at home, with friends, in discussions with $\mathrm{CO}^{-}$ workers as well as in the entertainment industry, advertising and the media. The theoretical frameworks for this chapter are studies in identity, the status of particular language varieties and developmental theories.

The chapter starts with a consideration of particular perceptions and attitudes towards Kaaps, even among those who use it daily and identify with it. How can such perceptions be changed?

\section{CHANGING PERCEPTIONS}

It is indisputable that Kaaps is an important medium of communication and a strong marker of identity especially on the Cape Flats. The contributions by Frank Hendricks, Michael le Cordeur and Dmitri Jegels in this journal edition confirm this fact. In this regard, Dyers (2008:67) sees Kaaps as “a powerful index of micro-networks, in-group identity and the exclusion of those who do not speak this variety". Despite this, Kaaps is seen as a language variety with an inferior status to Standard Afrikaans and English. Dyers (2008:53) highlights this perspective as follows:

'While its speakers acknowledge its low status in relation to the standard Afrikaans ..., it is fair to say that it enjoys a certain status as well as strong vitality in the poor, workingclass townships of the Cape Flats, a large area on the periphery of Cape Town'.

Many speakers of Kaaps refer to this variety with negative labels like 'Kombuisafrikaans' [Kitchen Afrikaans] and 'Mengels' [Mixed English] - a practice which can be related to their own identity issues in South Africa. It should be understood that this community was deeply scarred by colonialism and apartheid. Apart from having anecdotal information about family histories which may include slave, Khoi-Khoi and European ancestors, they are not adequately equipped with knowledge about their actual backgrounds. A lack of pride in their own identity consequently leads to a lack of pride in their home language - in this case, Kaaps. Breaking away from such negative attitudes towards Kaaps could aid in the awakening of a stronger self-image, which in turn can pave the way to economic development 
through Kaaps.

The perception among the speakers of Kaaps that it is a language variety with a low status is not unique. An international language like English was once seen as the language of the lower class. Today, English is the language of aspiration in many parts of the world, proving that the vitality of a language does not remain static. In a paper investigating the advantages of linguistic diversity and multilingualism this phenomenon is described as follows:

'First, it is important to consider that the vitality of a language is not static. Important languages, such as Latin have died and the vitality of many others has changed dramatically. For example, the extraordinary vitality that English enjoys nowadays has not been always been the same. After the Norman Conquest (1066), the king of England and his court were not fluent in English which was the language of the lower classes' (Gorter et al. 2007:13).

A similar tale is told by the path followed by the development of Standard Afrikaans since the 19th century. Giliomee describes it as follows:

'The English-speaking part of the population tended to consider Afrikaans as a public language beneath contempt. The Cape Argus, published in Cape Town, called Afrikaans a "miserable, bastard jargon, not worthy of the name of language at all"' (Giliomee 2003:4).

Given this background, the labelling of Kaaps as a low status language variety cannot be justified. Consideration needs to be given to initiating an awareness-raising process through information sessions which could change these perceptions and the ignorance underpinning such beliefs. The first symposium on Kaaps at the University of the Western Cape in July 2012, resulting in the book Kaaps in Fokus, was a conscious effort to change such perceptions about this language variety. The many educators who already incorporate Kaaps in their teaching should also be acknowledged (see the contribution by Le Cordeur in this journal).

Of central importance, however, is the theoretical foundation for such awareness-raising campaigns and the transfer of information.

\section{THEORETICAL FRAMEWORK}

Theoretically, this chapter is based on studies in language and identity as well as developmental theories.

As was shown in 8.2, the poor selfimage of many speakers of Kaaps also affects their attitudes towards this variety. In my view, this state of affairs emanates from the enforced racial categorizations of the apartheid era. Ferris, Peck and Banda (2014:422) contend as follows:

'Because of the apartheid system, many South Africans became keenly aware of their imposed race group and what it denoted in society, and this often led to racism. Race became strongly associated with economic, social and political power and privilege, or lack thereof. Notions of 'the other' were strongly emphasised in the apartheid laws which restricted, for example, the freedom of movement and use of public space by different racial groups.

State-enforced racial classification was probably the most difficult issue affecting the personal identities of those classified "Coloured", given the diversity of origins that typify this group. Today we realize that race, like identity, is merely 
a social construct and not a biological fact. But the racial stereotyping of the apartheid years still casts a giant shadow over South Africa: "Race continues to be one of the primary markers of identity in contemporary South Africa" '(Ferris et al. 2014:424).

I am convinced that this poor selfesteem, coupled with negative attitudes towards Kaaps among its own users, can be reversed - not just by awarenessraising campaigns, but also by economic development which places Kaaps at its centre, and subsequently improves its status. This contention is supported by an understanding of developmental theories.

In their book Communication for development in the Third World - Theory and Practice for Empowerment, Melkote \& Steeves (2001) highlight four developmental theories: modernisation, together with critical perspectives like the dependence theory, liberal perspectives and community theory.

The theory of modernisation assumes that the traditional practices in underdeveloped countries are primitive, and that Western economic practices and values are the only solutions that can place communities on the road to development and wealth creation. A classic example of modernisation is the multilayered theory of economic growth, introduced in 1960 by the American Walt Rostow. In this theory he proposes five levels for development in third world countries. These include the replacement of indigenous and traditional systems and practices with Western ones, the creation of a new political elite, centralized political structures, the alignment of political, social and institutional systems with economic outcomes, the development of people's technological and entrepreneurial skills, and the creation of mechanisms and structures to bring about high levels of mass consumption and spending. This model was severely criticized owing to its strong colonial stance, the dependence on Western capital and the subversion of indigenous languages, culture and knowledge.

In reaction to modernisation, the dependence theory argues that socialism is the solution to underdevelopment. Developing countries are encouraged to sever their links with Western capitalist countries, and to strive for self-sustenance and independence. Critics of this school of thought proffer the view that too much emphasis is laid on the identification of external stumbling blocks that prevent development. Consequently, this theory fails to rise above the level of rhetoric, or to develop meaningful and sustainable developmental alternatives.

Liberal perspectives contextualize development as an outflow of faith, and proceed from the assumption that various religions like Christianity, Buddhism, Hinduism, Islam and Judaism can have a significant impact on development. In total, these religions represent three-quarters of the world's population, and ostensibly act as catalysts which determine the nature and scope of development, as well as the tempo in which it takes place.

Community theory emphasizes the building of communities through a process of self-organisation. Key ingredients of self-organisation include ownership, self-help actions, institutional integration, consensus-building and social cohesion, and the exploitation of indigenous cultural treasures to achieve development, empowerment and sustainable wealth creation. Culture lies at the heart of all of this, as well as the drivers who create cultural content:

'The communitarian perspective attaches a higher value to human 
agency than either culturally or economically determinist views of social change. Culture and cultural constructions of reality, however, assume a central position in the communitarian perspectives'. (Tehranian 1994:286 in Melkotte and Steeves 2001:335)

In community theory, Kaaps is positioned as an important means of communication, a marker of identity and cultural driver in its speech community. It is the pivot for identification, association, interaction and mobilisation on the Cape Flats. Dyers confirms its importance as a defining marker of its speech community and the umbilical cord that binds them:

'the majority (speakers of Kaaps) identifies closely with the vernacular variety of Afrikaans that they use every day, ... The strong attachment of many members of this group to the works of poet and playwright, Adam Small, who wrote in vernacular 'Cape Flats' Afrikaans, the immense popularity of the music of rap and hip-hop artists who use it (e.g. Brasse vannie Kaap, Prophets of Da City) and the success of local theatrical productions like Joe Barber and Ghoema provide evidence of this close identification with this variety'. (Dyers 2008:53)

Community theory therefore confirms that there is no reason why a regional variety like Kaaps cannot be used as an instrument for economic empowerment, drawing especially on its artistic value in unlocking the means for sustainable development.

Successes in this regard are however few and far between. The most important reasons for this can be linked to a lack of organization, structure, support for artistic creativity as well as professional and sustainable financial management. Unlocking Kaaps as core artistic driver on a much greater scale is therefore possible if the speech community takes responsibility for the creation of a highly organized, professional and commercial cultural industry which devotes its time to concentrating on the creation of quality products.

In this regard, the famous and internationally known Motown music company serves as an excellent example. This is how its success was captured in Time magazine:

'Founded on Jan. 12, 1959, Motown quickly became another Detroit factory; where the Big Three produced automobiles, Motown assembled the soul and pop classics that changed America. There's no hyperbole in that statement. Arriving at the height of the civil rights movement, Motown was a black-owned, black-centered business that gave white America something they just could not get enough of - joyous, sad, romantic, mad, groovin', movin' music'. (http://www.time.com/time/ arts/article/0,8599,1870975,00. html\#ixzz2140koIMD)

Motown's role was however not limited to recordings, music tours and delivering famous music stars; it also played a key role in the development of people and the communities that gave birth to such talent. Wikipedia captures this as follows:

'Artist development was a major part of Motown's operations. The acts on the Motown label were fastidiously groomed, dressed and choreographed for live performances. Motown artists were advised that their breakthrough into the white popular music market 
made them ambassadors for other African American artists seeking broad market acceptance, and that they should think, act, walk and talk like royalty, so as to alter the lessthan-dignified image commonly held by white Americans in that era of black musicians. Given that many of the talented young artists had been raised in housing projects and were short on social and dress skills, this Motown department was not only necessary, it created an elegant style of presentation long associated with the label'. (http://en.wikipedia. org/wiki/Motown)

An important condition for the sustainable success of a cultural industry based on Kaaps, is whether there are any indications of a demand for products and services in this variety. This can only be revealed by an economic analysis of the speech community.

\section{AN ECONOMIC ANALYSIS OF THE KAAPS SPEECH COMMUNITY}

In this section, I analyse the population demographics of the brown speech community, the disposable income of this group, and the issues of supply and demand regarding Kaaps.

\section{Population demographics and disposable income}

The 2001 Census by Statistics South Africa reveals the following:

- Number of brown people living in South Africa: approximately 4.5 million

- Number of brown people living in the Western Cape: approximately 2.4 million
- Number of Afrikaans-speaking people living in the Cape Metropole: approximately 950000

- Number of English-speaking people living in the Cape Metropole: approximately 450000

- Size of the Kaaps speech community: approximately 700000

- Largest concentration of speakers of Kaaps:

\begin{tabular}{ll}
\hline Manenberg & 37390 \\
\hline Bonteheuwel & 40567 \\
Atlantis & 47150 \\
Mitchells Plain & 137589 \\
Blue Downs & 106823 \\
Belhar & 33575 \\
Hanover Park & 26305 \\
Lavender Hill & 16566 \\
Bishop Lavis & 21168 \\
Valhalla Park & 10837 \\
Ocean View & 10829 \\
Retreat & 15299 \\
\hline
\end{tabular}

An ethnographic study conducted by the OIL company in 2011 reveals the following:

'Fragmented, stereotyped and misunderstood, South Africa's 4.4 million strong coloured market is as big as the white market in South Africa, and makes up $63 \%$ of the total population in the Western Cape. Despite these statistics, many marketers overlook the obvious opportunity of marketing to the coloured population that has a combined spending power of over R60 billion per year'.

(http://www.oilinsight.co.za/ourwork/coloured-segmentation.php) 
The brown consumer market therefore equals the white market in terms of size, and the study also points out the diversity inherent in this market. For this reason, it is essential that a consumeroriented marketing philosophy be employed to determine the needs of the Kaaps speech community as target market. Supply and demand play key roles in such a needs analysis, and it is important to understand these core economic principles.

\section{Supply and demand}

According to Kotler and Keller (2006:174), cultural, social and personal factors determine the spending patterns of consumers. These factors are influenced by four key psychological processes - the ability to learn, motivation, perception and memory.

The commercialization of Kaaps through the print and electronic media, television and film, music and entertainment industries, the theatre and associated enterprises, can be successful if thorough planning and grounding adheres to following consumer behaviour model:

\begin{tabular}{|c|c|c|c|c|}
\hline $\begin{array}{l}\text { Marketing } \\
\text { stimuli }\end{array}$ & $\begin{array}{l}\text { Environmental } \\
\text { Stimuli }\end{array}$ & $\begin{array}{l}\text { Consumer } \\
\text { characteristics }\end{array}$ & $\begin{array}{l}\text { Consumer } \\
\text { decision-making } \\
\text { process }\end{array}$ & $\begin{array}{l}\text { Decision to } \\
\text { purchase }\end{array}$ \\
\hline Product range & Economy & Cultural factors & $\begin{array}{l}\text { Problem } \\
\text { identification }\end{array}$ & $\begin{array}{l}\text { Choice of } \\
\text { product }\end{array}$ \\
\hline $\begin{array}{l}\text { Marketing } \\
\text { communication }\end{array}$ & Politics & Social factors & $\begin{array}{l}\text { Gathering } \\
\text { information }\end{array}$ & $\begin{array}{l}\text { Choice of } \\
\text { trademark }\end{array}$ \\
\hline Place & Culture & Personal factors & $\begin{array}{l}\text { Evaluating } \\
\text { alternatives }\end{array}$ & Choice of dealer \\
\hline Price & Culture & $\begin{array}{l}\text { Consumer } \\
\text { Psychology }\end{array}$ & $\begin{array}{l}\text { Decision to } \\
\text { purchase }\end{array}$ & Cost of item \\
\hline Participants & & Attitude & $\begin{array}{l}\text { Evaluation post- } \\
\text { purchase }\end{array}$ & $\begin{array}{l}\text { Calculation of } \\
\text { time used for } \\
\text { purchase }\end{array}$ \\
\hline \multirow[t]{5}{*}{ Physical evidence } & & Preference & & $\begin{array}{l}\text { Method of } \\
\text { payment }\end{array}$ \\
\hline & & Ability to learn & & \\
\hline & & Motivation & & \\
\hline & & Perception & & \\
\hline & & Memory & & \\
\hline
\end{tabular}

Source: adapted from Kotler and Keller (2006:184) 
What is especially interesting in the model by Kotler and Keller is their core focus on consumer characteristics (cultural, social and personal factors) and consumer psychology (attitude, preference, ability to learn, motivation, perception and memory). Marketing agents therefore cannot ignore the language and identity issues of consumer communities. How does a specific product get sold to speech communities? How are connections made with the community's language and cultural preferences? Why have some advertisements enjoyed more popularity among different population groups than others? To answer these questions, I refer to a study by Saal and Blignaut (2011), which focuses on the usage and value of Teenage Kaaps in print advertisements. Elements of Kotler and Keller's consumer behaviour model can definitely be seen in this study.

The study confirms the commercial value of Kaaps and that it can be used successfully as a medium for advertising in the print media. Here are two advertisements in Standard Afrikaans, followed by the Teenage Kaaps versions.

1. KitKat advertisement in Standard Afrikaans:

Lief,
vergewe my
asseblief,
was bietjie kwaad;
sien jou vandag
by die skool?
Moet nou gaan;
lief vir jou
Neem 'n blaaskans, eet ' $n$
KitKat.

[Sweety, please forgive me, was a little cross; see you at school today? Got to go; love you. Have a break, have a KitKat].
2. Advertisement about HIV testing in Standard Afrikaans:

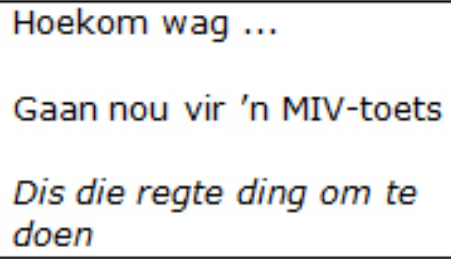

[Why wait...get tested for HIV now. It's the right thing to do].

1. Kit Kat Advertisement in Teenage Kaaps:

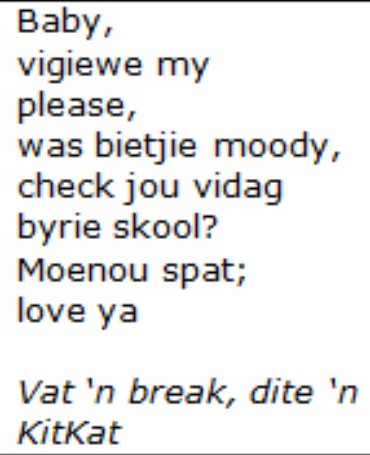

2. Advertisement about HIV testing in Teenage Kaaps:

Hoeko wag..
Maats nou vi 'n HIV-test
Disi right choice om te dala

According to Saal and Blignaut, the use of Teenage Kaaps was very positively received by young speakers of the variety.

This study is only one example of the impact Kaaps has in advertisements. Popular songs in Kaaps (like the minstrel song "Januarie, Februarie, Maart" - "January, February, March") are frequently incorporated in product marketing, as well as the witty 
commentary so typical of speakers of Kaaps. An example of the latter is the on-line company Vannie Kaap, which has built a successful business by selling products like mugs and t-shirts on which such sayings are printed.

But everyone engaged in the commercialization of Kaaps should be well-informed regarding the issue of copyright. The commercialization of various aspects of indigenous knowledge systems, heritage and cultural treasures point to a long history of exploitation and the failure to recognize the original owners of such systems and treasures. Indigenous intellectual copyright applies to all cultural practices like music, dance, story-telling and knowledge which has been passed on from generation to generation. Artists should be wellinformed regarding the laws and policies regarding copyright. The law regarding copyright in South Africa is the Copyright Law of 1978 and its associated additions. It is administered by the Companies' and Intellectual Properties Commission of the Department of Trade and Industry.

Copyright, especially regarding the exploitation of cultural treasures, forms part of the potential building blocks for the promotion of Kaaps as a language of economic empowerment. These building blocks are discussed in the following section.

\section{TO CONGLUDE: BUILDING BLOCKS FOR A STRATEGIC AND OPERATIONAL PLAN}

The following steps could serve as building blocks for a strategic and operational plan designed to promote Kaaps as a language of economic empowerment:

- Identifying of the various entities using Kaaps in a range of cultural practices in communities.

- Establishinga strong commercialized cultural industry using Kaaps as key artistic driver.

- Identifying of all the spheres where Kaaps plays/can play a role: e.g. in education, publication, advertising, the print media, communication technology, radio, television, film, language practitioners, electronic communication media, theatre, design, fashion, entertainment, heritage, tourism and cultural festivals.

- Being creative and innovative in the use of Kaaps in self-sustaining, integrated and creative economic activities, ensuring quality projects and programmes.

- Monitoring, evaluating and redesigning projects and programmes to ensure that they truly add value and contribute to the development of communities.

- Marketing projects and programmes, keeping the community informed, and strengthen these with supporting mechanisms to ensure longterm sustainability and growth.

The continued development of Kaaps as a language of economic empowerment and wealth creation is in the hands of its speakers. The time is ripe for all practitioners, academics and other role players with an interest in Kaaps, to turn theory into practice.

\section{REFERENGES}

Dyers, Charlyn. 2008. Language Shift or Maintenance? Factors Determining the Use of the Afrikaans Language among 
Some Township Youth in South Africa.

Stellenbosch Papers in Linguistics (SPIL) 38: 49-72.

Ferris, Fiona, Amiena Peck and Felix Banda. 2014. Language and Identity. In: Zannie Bock and Gift Mheta (eds.) Language, Society and Communication: An Introduction. Pretoria: Van Schaik, bl. 409-425.

Giliomee, Hermann. 2003. The Rise and Possible Demise of Afrikaans as a Public Language. PRAESA Occasional Papers, 14. Cape Town: PRAESA.

Gorter, Durk, Jason Cenoz, Paulo Nunes, Patrizia Riganti, Laura Onofri, Barbara Puzzo and Rajesh Sachdeva. 2007.

Cultural diversity as an asset for human welfare and development. http://ebos.com. cy/susdiv/uploadfiles/RT1.2_SP_Durk.pdf

Kotler, Phillip T. and Kevin Lane Keller. 2006. Marketing Management. New Hampshire: Prentice Hall.

Melkote, Srinivas R. en H.Leslie Steeves. 2001. Communication for Development in the Third World: Theory and Practice for Empowerment. London: Sage Publications.
Ponelis, Fritz.A. 2009. Die taal wat ons praat, By, Saturday 19/12/2009.

Saal, Elvis, and Joline Blignaut. 2011. Die gebruik en waarde van 'n Tienerkaaps in gedrukte advertensies. Pretoria: Departement Afrikaans en Algemene Literatuurwetenskap, UNISA. http:// www.litnet.co.za/Article/moetie-raigammattaal-gebrykie-die-gebruik-enwaarde-van-n-tienerkaaps-in-gedrukte http://www.time.com/time/arts/ article/0,8599,1870975,00. html\#ixzz2140koIMD http://www.oilinsight.co.za/our-work/ coloured-segmentation.php http://en.wikipedia.org/wiki/Motown

Christo van der Rheede contributed this chapter in his previous capacity as Executive Director of the Foundation for Empowerment through Afrikaans (SBA). Currently, he is Deputy Director of AGRI SA, and recently became the Chairperson of AgriSeta. 